\title{
Antibacterial activity of ginger extracts and its essential oil on some of pathogenic bacteria
}

\author{
Mohammed Ibraheem Nader* \\ Safaa Abdalrasool Ali*
}

\author{
Kais Kassim Ghanima* \\ Dalia Ahmad Azhar**
}

Received 1, May, 2009

Acceptance 7, September, 2009

\begin{abstract}
:
The antimicrobial activity of ginger extracts ( cold-water, hot-water, ethanolic and essential oil ) against some of pathogenic bacteria ( Escherichia coli, Salmonella sp , Klebsiella sp , Serratia marcescens, Vibrio cholerae, Staphylococcus aureus, Streptococcus sp) was investigated using Disc diffusion method, and the results were compared with the antimicrobial activity of 12 antibiotics on the same bacteria .

The results showed that the ginger extracts were more effective on gram-positive bacteria than gram-negative . $V$. cholerae and $S$. marcescens, were the most resistant bacteria to the extracts used, while highest inhibition was noticed against Streptococcus sp $(28 \mathrm{~mm})$. The ethanolic extract showed the broadest antibacterial activity ( 11 to $28 \mathrm{~mm}$ ), in comparison with moderate activity of essential oil , it was observed that the cold-water extract was more effective on the bacteria than hot-water extract .

Ginger ethanolic extract presented higher diameter of inhibition zone for Streptococcus sp than in Ciprofloxacin, Cefotaxime, Cefalotin, Cephalexin and Cephaloridine, also it was found a similarity between the higher inhibition zones of ethanolic extract of ginger and some antibiotics for S. aureus , E. coli, Salmonella sp and Klebsiella sp. V. cholerae and S. marcescens, also highly resistant to antibiotics . Phytochemical analysis of ethanolic extract of ginger revealed the present of glycosides, terpenoids, flavonids and phenolic compounds
\end{abstract}

Key words: Antibacterial activity, ginger extracts.

\section{Introduction :}

Ginger (Zingiber officinale) is member of the zingiberaceae family of plant that include cardamom and turmeric. The strong aroma of ginger is the result of pungent ketones including gingerol [1].The medicinal use of ginger rhizome dates 2,500 years in china and India, where it was prescribed to treat headaches, nausea, rheumatism and colds [2].Ginger has been shown to have antimicrobial activity against pathogenic bacteria such as Escherichia coli, Proteus sp., staphylococci, streptococci and Salmonella [3,4].The ginger has the capacity to eliminate harmful bacteria responsible for most of the diarrhoea, especially in children. It has been shown to reduce the stickiness of blood platelets, hence may help reduce risk of arthrosclerosis[5], antimicrobial activity of spices and herbs has been known and described for several centuries. At present, its estimated that about $80 \%$ at world population rely on botanical properties of medicines to meet their health need. Herbs and spices are generally considered safe and proved to be effective against certain ailments [6].

*Institute of Genetic Engineering and Biotechnology for Post Graduate Studies, University of 
Since the introduction of antibiotics there has been tremendous increase in the resistance of diverse bacterial pathogenes [7]. The enterococci have intrinsic resistance to multiple antimicrobials, most drug resistance in enteric bacteria is attributed to the wide spread transmission of resistance plasmid among different genera [8]In the present study we have evaluated the antibacterial effect of the extracts of ginger against some of pathogenic bacteria. The inhibitory effect of ginger was compared with the effect of 12 antibiotics and the results are discussed and also find out the phytochemical active constituents.

\section{Materials and Methods:}

The bacterial isolates E.coli,Salmonella sp, klebsiella sp, S. marcescens, and $V$. choierae were isolated from gastrointestinal infections, also $S$. aureus and Streptococcus sp were isolated from respiratory tract infections. All the bacteria were obtained, as clinical isolated, from Al-Yarmook teaching hospital in Baghdad. Bacterial cultures were maintained on Nutrient agar(NA)Slopes. They were subcultured monthly and subsequently stored at $4^{\circ} \mathrm{C}$.

\section{Culture preparation}

Aloopfull of $24 \mathrm{hr}$. surface growth on a NA slope of each bacterial isolate was transferred individually to $5 \mathrm{ml}$ of Brain heart infusion broth(PH 7.6)and incubated at $37^{\circ} \mathrm{C}$ for $24 \mathrm{hr}$, bacterial cells were collected by centrifugation at 3000rpm for $15 \mathrm{~min}$., washed twice and resuspended in $0.1 \%$ pepton water. Turbidity was adjusted to match that of as Mcfarland standared $\left(10^{8} \mathrm{CFU} / \mathrm{ml}\right)$. Then 1:10 dilution of the cell suspension was performed to give an inoculum concentration of $10^{7} \mathrm{CFU}$ $/ \mathrm{ml}$.

\section{Ginger extraction}

The ginger rhizomes were washed with clean sterile distilled water and allowed to air-dry for one hour, then the outer covering of the ginger were manually peeled off and the ginger was washed again and extracted using the following procedures:

\section{A-cold-water extraction}

Exactly $20 \mathrm{~g}$ of fresh ginger rhizomes were blended into fine powder and soaked in $100 \mathrm{ml}$ of distilled water for $24 \mathrm{hr}$. The pulp obtained was left in aclean ,sterile glass container and shaken at $150 \mathrm{rpm}$ for $8 \mathrm{hr}$ vigorously to allow for proper extraction and it was filtered using asterile muslin cloth after which the extract was obtained, air-dried and stored below ambient temperature until required[9]

\section{B-Hot-water extraction}

Exactly $20 \mathrm{~g}$ of fresh ginger rhizomes were blended and soaked in $100 \mathrm{ml}$ of hot water at $80 \mathrm{C}$ (shaker water bath) at $150 \mathrm{rpm}$ for $24 \mathrm{hr}$., the resulted juice was extracted air- dried and storied as in above [9].

\section{C-Crude ethanolic extraction.}

$20 \mathrm{~g}$ of small pieces of fresh ginger rhizomes were soaked in $100 \mathrm{ml}$ of $95 \%$ ethanol and shaken at 150rpm for $24 \mathrm{hr}$ at ambient temperature the mixture then filtered. The filterates were evaporated using vacuum rotary evaporator,and frozen at $-20^{\circ} \mathrm{C}$.Stock solutions of crude ethanolic extracts were prepared by diluting the dried extracts with $10 \%$ dimethyl sulphoxide (DMSO)solution[9].

\section{D-Essential oils}

$300 \mathrm{~g}$ of small pieces of fresh ginger rhizomes with distilled water (1L) were placed in flask (2L) together after steam distillation, the essential oils were collected, dispensed into dark bottles, and stored at $4^{\circ} \mathrm{C}$ until used [10]. 
Antibacterial screening test of extracts using disk diffusion method.

The disk diffusion test was performed using standard procedure by Jorgensen et al. [11].The inoculum suspension of each bacterial isolate was swabbed on the entire surface of Muller-Hinton agar (MHA)(pH7.3). Sterile $6 \mathrm{~mm}$ filter paper discs (Watman No.3) were aseptically placed on MHA surface, and crude ethanolic extract, essential oil, hot -water extraction and cold water extraction were immediately added to discs in volume of $20 \mathrm{ml}$. A $20 \mathrm{ml}$ aliquot of $10 \%$ DMSO and distilled water were also added to a sterile paper discs as a negative control, whereas an antibiotic screening by disc method used as a positive control.

The plates were left at ambient temperature for $15 \mathrm{~min}$. to allow excess predifferent of extraction prior to incubation at $37^{\circ} \mathrm{C}$ for $24 \mathrm{hr}$. Diameters of inhibition zone were measured each experimental was done in duplicate.

Inhibition zone with diameter less than $12 \mathrm{~mm}$ were considered as having no antibacterial activity ,diameter between 12 and $16 \mathrm{~mm}$ were considered moderately active, and these with $>16 \mathrm{~mm}$ were considered moderately active[12].

\section{Antibiotic sensitivity testing (antibiogram).}

The test microorganisims were also tested for their sensitivity by Discdiffusion method ( Kirby-Bauer method ) [13] against the antibiotics manufactured by Bioanalyse and Oxoid in 2008 with the concentration $(\boldsymbol{\mu g} /$ disc $) \quad, \quad$ Penicillin $\mathrm{G}(10)$, Ampicilin(10), Cefotaxime(30), Cephalexin(30), Cefalotin(30),

Cephaloridine(30), Trimethoprime sulphamethoxazole $(1.25+23.75)$,

Tetracyclin(30), Erthromycin(15), Kanamycin(30), Vancomycin(30) and Ciprofloxacin(10)

\section{Phytochemical anylysis}

The identification tests were done to find the presence of the active chemical constituents such as alkaloids, glycosides, terpenoids, flavonids, phenolic compounds, reducing sugars and tannins by the procedures as described by Siddiqui and Ali (1997)[14]

\section{Result and Discussion:}

The results of antibacterial activity of ginger extracts (cold-water, hot-water, crude ethanolic and essential oil)on the pathogenic bacterial isolates (E. coli, Salmonella sp, klebsiella sp, $S$. marcescens, V. cholera,S. aureus and Streptococcus $s p$ ) are shown in table(1).

Table (1): Antibacterial activity of crude extracts of ginger against some of pathogenic bacteria.*

\begin{tabular}{|r|c|c|c|c|c|}
\hline \multirow{2}{*}{ No. } & $\begin{array}{c}\text { pathogenic } \\
\text { bacteria }\end{array}$ & $\begin{array}{c}\text { Dold -water } \\
\text { extract(100 } \\
\%)\end{array}$ & $\begin{array}{c}\text { hot -water } \\
\text { extract(100 } \\
\%)\end{array}$ & $\begin{array}{c}\text { Ethanolic } \\
\text { extract(100 } \\
\%)\end{array}$ & $\begin{array}{c}\text { Essentia } \\
1 \\
\text { oil(100 } \\
\%)\end{array}$ \\
\hline 1. & $\begin{array}{c}\text { Escherichia } \\
\text { coli }\end{array}$ & 16 & 10 & 18 & 12 \\
\hline 2 & $\begin{array}{c}\text { Salmonella } \\
\text { sp. }\end{array}$ & 18 & N.I.** & 20 & 17 \\
\hline 3 & $\begin{array}{c}\text { Klebsiella } \\
\text { sp. }\end{array}$ & 14 & 10 & 18 & 14 \\
\hline 4 & $\begin{array}{c}\text { Serratia } \\
\text { marcescens }\end{array}$ & N.I. & N.I. & 11 & N.I. \\
\hline 5 & $\begin{array}{c}\text { Vibrio } \\
\text { cholerae }\end{array}$ & N.I. & N.I. & 10 & 8 \\
\hline 6 & $\begin{array}{c}\text { Staphylococ } \\
\text { cus aureus }\end{array}$ & 18 & 8 & 24 & 18 \\
\hline 7 & $\begin{array}{c}\text { Streptococcu } \\
\text { sp. }\end{array}$ & 14 & 11 & 28 & 20 \\
\hline
\end{tabular}

*Data are means of two replications. ** N.I.:No. Inhibition.

The results of this work indicates that the ginger extracts were more effective on gram-positive bacteria (the widest zone of inhibition was $28 \mathrm{~mm}$ ) than on gram negative bacteria (the widest zone of inhibition was $20 \mathrm{~mm}$ ). This is probably due to the differences in cell wall structure of gram-positive bacteria and gram negative bacteria. These results agree with observations of theAkoachere et al. [15], who had reported that the extracts of ginger exhibited antibacterial activity against the pathogens S.aureus and 
Streptococcus pyogenes .Highest inhibition was noticed against Streptococcus (with highest inhibition zone $28 \mathrm{~mm}$ ).

In gram negative bacteria it was observed that ginger extracts(except hot-water extract ) had activity on $E$. coli, Salmonella sp and Klebsiella sp ( the range of inhibition zone was 12 to $20 \mathrm{~mm}$ ) , while S.marcesces and V.cholerae were the most resistant bacteria to all extracts used. These results are contradictory to the observations of Indue et al.[12], who had reported that the ginger extracts did not show any antibacterial activity against all serogroups of E.coli and Salmonella sp. The differences may be due to a difference in the variety of the ginger used in this study, the difference in the strains of pathogenic bacteria and the source of samples .

The ethanolic extract of ginger showed the broadest antibacterial activity by inhibiting growth of all bacterial isolate tested (the diameter of inhibition zone,11-28mm).This credit to ethanol extraction was supposed to ethanol being an organic solvent and will dissolve organic compounds better, hence liberate the active component such as zingerone, gingerol and shogaol required for antimicrobial activity [5]
It was observed that the cold -water extract of ginger was more effective on the bacteria than hot-water extract, this may be explained by the fact that the antimicrobial substances in the ginger extract are destroyed by heat from the hot-water which might have raised the temperature of the extracts inactivating them[16].Nelson et al. [5] explain that the antimicrobial substance in the extract are mainly phenolic compounds were destroyed or inactivated by heat . Ginger essential oil possessed moderate antibacterial activity in this study. The major pungent compound of ginger are gingerone and gingerol which have strong inhibitory activity against pathogenic bacteria [17]. These result disagree with observations of Suree and Pana [18], who obtained that the inhibitory activity of essential oil was greater than that of ethanolic extract. The greater effect of ethanolic extract compared to the other may be due to that plant extract in organic solvents provided more cnsistent antimicrobial activity, also we think that the ginger oil has therapeutic properties such as analgesic, antiemetic and antispasmodic more than antibacterial properties .

The antimicrobial susceptibility results for the pathogic bacterial isolates against commonly used antibiotics are summarized in table (2).

Table (2) antimicrobial susceptibility of some pathogenic bacteria to antibiotics.*

\begin{tabular}{|c|c|c|c|c|c|c|c|c|}
\hline no & Anitbiotic & E.coli & Salmonella & Klebsiella & S.marcescens & V.cholerae & S.aureus & Streptococcus \\
\hline $1-$ & Penicillin G & $\mathrm{R}^{*}$ & $\mathrm{R}$ & $\mathrm{R}$ & $\mathrm{R}$ & $\mathrm{R}$ & $\mathrm{R}$ & $\mathrm{R}$ \\
\hline $2-$ & Ampicillin & $\mathrm{R}$ & $\mathrm{R}$ & $\mathrm{R}$ & $\mathrm{R}$ & $\mathrm{R}$ & $\mathrm{R}$ & $\mathrm{R}$ \\
\hline $3-$ & Cephalexin & $\mathrm{R}$ & $16^{* *}$ & $\mathrm{R}$ & 15 & $\mathrm{R}$ & 20 & 18 \\
\hline $4-$ & Cefalotin & 22 & $\mathrm{R}$ & $\mathrm{R}$ & $\mathrm{R}$ & 17 & 16 & 19 \\
\hline $5-$ & Cephaloridine & $\mathrm{R}$ & $\mathrm{R}$ & 15 & $\mathrm{R}$ & $\mathrm{R}$ & 16 & 18 \\
\hline $6-$ & Cefotaxime & $\mathrm{R}$ & 18 & $\mathrm{R}$ & 24 & $\mathrm{R}$ & 24 & 20 \\
\hline $7-$ & $\begin{array}{c}\text { Trimetoprime- } \\
\text { sulphamethaxozol }\end{array}$ & 18 & $\mathrm{R}$ & 20 & $\mathrm{R}$ & $\mathrm{R}$ & $\mathrm{R}$ & $\mathrm{R}$ \\
\hline $8-$ & Tetracyclin & $\mathrm{R}$ & $\mathrm{R}$ & $\mathrm{R}$ & $\mathrm{R}$ & $\mathrm{R}$ & 16 & $\mathrm{R}$ \\
\hline $9-$ & Erthromycin & $\mathrm{R}$ & $\mathrm{R}$ & $\mathrm{R}$ & $\mathrm{R}$ & $\mathrm{R}$ & $\mathrm{R}$ & $\mathrm{R}$ \\
\hline $10-$ & Kanamaycin & 20 & 18 & $\mathrm{R}$ & $\mathrm{R}$ & 17 & 20 & 14 \\
\hline $11-$ & Vancomycin & $\mathrm{R}$ & $\mathrm{R}$ & $\mathrm{R}$ & $\mathrm{R}$ & 10 & 14 & 12 \\
\hline $12-$ & Ciprofloxacin & 22 & $\mathrm{R}$ & 18 & $\mathrm{R}$ & 16 & 25 & 22 \\
\hline
\end{tabular}

*The results of sensitivity to antibiotics were performed in accordance with NCCLS guidelines (19).

R: Resistant

** The number is mean the inhibition zone in $\mathrm{mm}$.(the bacteria intermediate sensitive or susceptible to antibiotic) 
The results showed that all isolates were resistant to 3 or more antibacterial and defined as multidrug resistant. Ginger extract presented higher diameter of inhibition zones for Streptococcus sp than in Ciprofioxacin, Cefotaxime, Cefalotin, Cephalexin, and Cephaloridine.

It was found there is a similarity between the higher inhibition zones of ethanolic extract of ginger and some antibiotics for S.aureus, E.coli, Salmonella sp , and Klebsiella sp, also observed that V.cholerae and $S$. marcescens highly resistant to antibiotics as in their resistant to ginger extracts and this had led to the suggestion that there may be the presence of multiple plasmids in the mutants or plasmid carrying multiple resistance determinants[20].Also as in the effect of antibiotics it was suggested that the antimicrobial action of spices is due to the impairment of variety of enzymes systems involving in the production of energy or synthesis of structural components in microbial cells [21].

Phytochmical analysis of ethanolic extract of ginger revealed the presence of glycosides, terpenoids, flavonids and phenolic compounds (table 3). It has been observed that there is a possibility of synergism between the active compounds in the crude extract than in isolated constituents [22]. Acetone and ethanol extracts of ginger contains pungent substances namely Oleoresin (gingerol and shagaol), phenols(zingerone and gingeol ) and paradol [23]. Hydroethanolic ginger extract exhibited potent antibacterial activity against gram positive and gram negative bacteria, this effect may be due to gingerols and phenolic compounds[24]

Table (3) chemical constituents of ethanolic extract of ginger.

\begin{tabular}{|c|c|c|c|c|c|c|c|}
\hline $\begin{array}{c}\text { The type } \\
\text { of extract }\end{array}$ & Alcaloids & Glycosides & terpenoids & Flavonids & $\begin{array}{c}\text { phenolic } \\
\text { compounds }\end{array}$ & $\begin{array}{c}\text { Reducing } \\
\text { sugars }\end{array}$ & Tannins \\
\hline $\begin{array}{c}\text { Ethanolic } \\
\text { extract }\end{array}$ & $-\mathrm{ve}$ & $+\mathrm{ve}$ & $+\mathrm{ve}$ & $+\mathrm{ve}$ & $+\mathrm{ve}$ & $-\mathrm{ve}$ & $-\mathrm{ve}$ \\
\hline
\end{tabular}
+ve=detected $-\mathrm{ve}=$ not detected

\section{References:}

1-DerMarderosian, A. and Beutler. J.A.2006.The Review of Natural Products. St. Louis, $5^{\text {th }}$ ed. California.

2-Grzanna,R. , Lindmark K. .L and Frandozo. C. G. 2005. Ginger -an herbal medicinal product with broad anti-inflammatory actions. J. Med. Food. 8(2):125-132.

3-Gugnanti, H.C. and Ezenwanze. E. C. 1985. Antibacterial activity of extracts of ginger (Zingiber officinale) and African oil bean seed (Pentaclenthora macrophylla). J. Commun Dis. 17:233-239.

4-Habsah, M., Amran. M., Mackeen . M. M. , Lagis. N .H . ,K ikuzaki. H . , Nakatani. N. , Rahman ,. A. A . and Ali Ghafar. A. M. 2000. Screening of zingiberaceae extract for antimicrobial of antioxidant activities. J.Ethnopharmacol. 72: 403-410 .

5- Nelson, C. A. , Reginald. A. O. , Okoro. N and Janet. K. 2007. Antibacterial activity of Allium cepa (Onion) and Zingiber officinale (ginger) on Staphylococcus aureus and Pseudomonas aeruginosa isolated from high vaginal swab. The Internet. J. of Tropical medicine, 3(2):122-130.

6- Bagnmbaula, C.F., Uyttenduele M.,Debervere.J.2003. Antimicrobial effect of spices and herbs on Shigella sonnei and S.flexneri.J.Food prot.66:668-673.

7-Neu, L.H. 1992. TheCrisis in antibiotic resistance. Science. 257:1054-1075. 
8- Jawetz, M. , Brooks. G. F. ,Batel. J. S. and Morse. S. A. 1998. Medical microbiology $21^{\text {th }}$.ed. Applton and Lange, California

9-Harborrne, J.B.1984. Phytochemical methods. Chapman and Hill. London

10-European Pharmacopoeia. 1975. vol.3, Maisonne uve SA, Sainte Ruffine, pp.68.

11-Jorgensen, J. H ., Turidge. J.D. And Whashington. J. A. 1999. Antibacterial Susceptibility Tests:Dilution and Disk Diffusion methods.In:Murray, P. R., Barron. E. J. , Praller. M. A. , Twnover. E. C. and Yollken. R. H. , Eds. Manual of Clinical Microbiology. A J M press., Washington, DC. , PP. 1526-1562.

12-Indue, M. N. , Hatha. A. A. M. , Abirosh. C. , Harsha. U. and Vivekanandan. G. 2006. Antimicrobial activity of some of the south -indian spices against serotyper of Escherichia coli, Salmonella, Listeria monocytogenes and Aeromonas hydrophila. Brazillian Jornal of Microbiology. 37(2):147-158.

13-Reeves, D. S. , Philies. I. , Williams. J. D. and Wise. R. 1978. Laboratory methods in antimicrobial chemotherapy . Churchill living stone, New York.

14- Siddiqui, A.A.and Ali.M .1997. Practical Pharmaceutical chemistry .Is ted., CBS Publishers and Distribuiters,New Delhi, pp. 126131

15-Akoachere, J .F. , Ndip. R. N. , Chenwi. E. B. and Anong. D. N. 2002. Antibacterial effect of zingiber officinale and Garcinia Kolao on respiratory tract pathogens. East Afr. Med. J. 79:588-592.

16-Chen, H. C. ,Chang. M.D.and Chang. T.J.1985. Antibacterial properties of some spice plants before and after heat treatment . Pubmed . 81(3):190-195.

17-Hirasa, K. and Takemasa. M. 1998. Spice science and technology .Marcel Dekker Inc. , NewYork.

18-Suree, N. and Pana. L. 2005. Antibacterial activity of crude ethanolic extracts and essential oils of spices against Salmonellae and other enterobacteria. KMITL Sci. Tech. J. 5(3):572-583.

19-National Committee for Clinical Laboratory Standards. 1999. Performance standards for antimicrobial susceptibility testing. 9 th ed . , informational supplemented. Wayne ,P . A. :National Commitee for Clinical Laboratory Standards.

20-Martinez - Martinez, L. , Hernandez- Alles. S.and Alberti. S. 1996. In vivo selection of porin deficient mutants of Klebsiella Pneumoniae with increased resistance to cefoxitin and expanded -spectrum cephalosporins. Antimicrob Agent. Chemother. 40:342-348.

21-Wickins,K. M. and Board . R. G. 1989. Natural antimicrobial systems. In:Gould, G. W. , Ed. Mechanisms of action of food preservation procedures . El sevier , Landon, pp. 285.

22- Daniel, M.2004.Impediments preventing India becoming a herbal giant . Current Science . 87:275276.

23-Mustafa, T.,Srivastara, K.C. and Jansen. K.B. 1993. Drug Development Report(9), Pharmacology of ginger, Zingiber officinale. J.Drug Dev.6:24-30.

24- Muscolo, N.,jain S.C. and Capasso .f.1989. Ethnopharmocologic investigation of ginger, Zingiber officinale .J. Ethnopharmacol. 27:129-140 


\section{الفعالية المضادة للبكتريا لمستخلصات الزنجبيل وزيته العطري في بعض البكتريا الممرضة الترنيلة}

صفاء عبل الرسول عليث

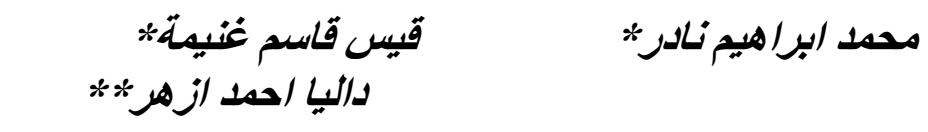

* معهد الهندسة الور اثية و التقنيات الاحيائية للار اسات العليا /جامعة بغداد

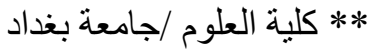

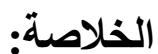

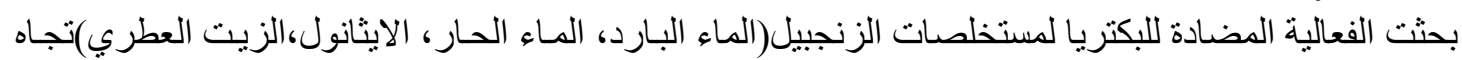

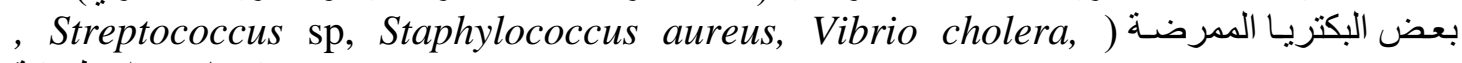
( Serratia marcescens , Salmonella sp, Escherichia coli,Klebsiella sp الانتشار بالقرص وقورنت النتائج مع تأثير 12 مضاد في هذه البكتريا .



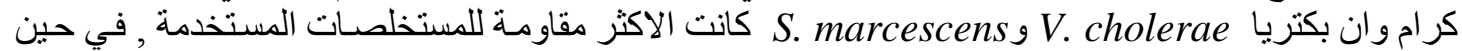

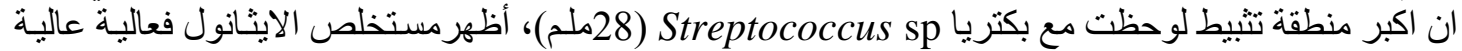

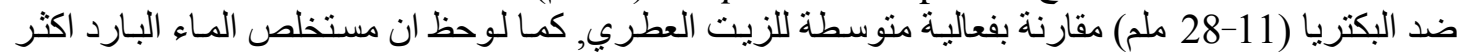
فعالية ضد البكتريا من مستخلص الماء الماء الحار .

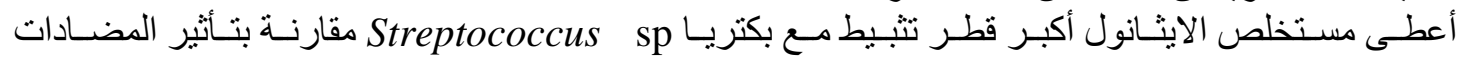

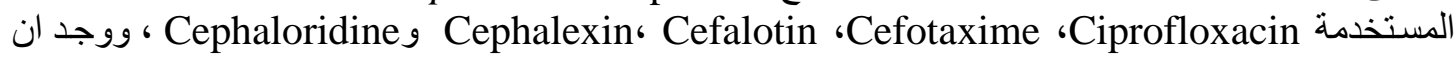
S. aureus , E. coli , هنالك تثـابها بين مناطق التببيط للمستخلصات و بعض المضادات تجاه بكتريات

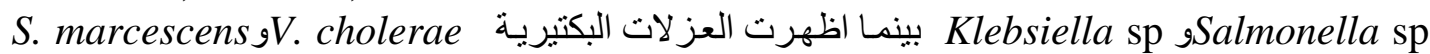

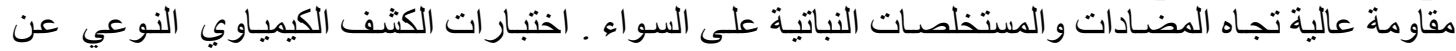

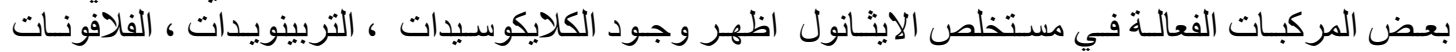
و المركبات الفينولية . 